\title{
ANALISIS PENGARUH PANJANG ELEMEN TERHADAP KUAT TEKAN DARI BAJA RINGAN PROFIL KANAL DENGAN METODE ELEMEN HINGGA
}

\author{
Denny Stevens ${ }^{1}$ dan Leo S. Tedianto ${ }^{2}$ \\ ${ }^{1}$ Program Studi Sarjana Teknik Sipil, Universitas Tarumanagara, Jl.Letjen S. Parman No.1 Jakarta \\ Email: dennysteven96@gmail.com \\ ${ }^{2}$ Program Studi Sarjana Teknik Sipil, Universitas Tarumanagara, Jl.Letjen S. Parman No.1 Jakarta \\ Email:leotedi@gmail.com
}

\begin{abstract}
ABSTRAK
Cold-formed Steel atau sering disebut baja ringan adalah material yang akhir-akhir ini sering digunakan karena harganya lebih ekonomis dibanding dengan baja konvensional. Profil ini memiliki titik leleh yang lebih tinggi dibanding baja konvensional dengan tebal yang lebih tipis. Karena tebalnya yang sangat tipis, profil-profil baja ringan sangat rawan terjadi tekuk lokal. Oleh karena itu profil baja ringan kebanyakan didesign memiliki pengaku pada web dan flensnya untuk memperkecil kemungkinan terjadinya tekuk lokal. Tekuk lokal sendiri dipengaruhi oleh panjang elemen. Semakin pendek elemen, kecenderungan terjadinya tekuk lokal akan semakin besar. Analisis ini bertujuan untuk mencari pengaruh panjang elemen terhadap kuat tekan kritisnya dan melihat tekuk yang terjadi dengan cara teoritis dan metode elemen hingga. Profil yang digunakan adalah $75 \mathrm{~mm} \times 35 \mathrm{~mm} \times 5 \mathrm{~mm}$ x $0,65 \mathrm{~mm}$ dengan pengaku pada badan dan flensnya. Perhitungan metode elemen hingga dilakukan dengan program Abaqus. Pemodelan panjang yang digunakan adalah 500, 1000, 1500, 2000, 2500 dengan perletakan tetap sendi-sendi, arah beban sejajar dengan batang (aksial). Hasilnya adalah semakin panjang elemen kuat tekan batang akan semakin kecil dan deformasi yang dihasilkan akan semakin besar. Tekuk yang terjadi adalah tekuk lokal pada bagian flens yang menunjukan kurangnya pengaku pada bagian flens.
\end{abstract}

Kata kunci: Cold-formed steel, tekuk lokal, tegangan, defleksi, metode elemen hingga.

\section{PENDAHULUAN}

\section{Latar Belakang}

Dalam teknik sipil, akhir-akhir ini sedang ramai dibicarakan penggunaan baja ringan sebagai pengganti bahan baja Hot-rolled dan kayu. Selain murah, pemasangannya juga lebih cepat dibandingkan dengan kayu, sehingga pemakaian baja ringan semakin banyak dicari oleh konsumen. Penggunaan baja ringan sebagai rangka atap memiliki banyak kelebihan jika dibandingkan dengan kayu atau baja Hot-rolled, seperti sifat seragam, tahan terhadap rayap, pemasangan lebih cepat, dan masih banyak lagi. Di pasaran biasanya terdapat 3 bentuk profil baja ringan yang sering ditemui, yaitu profil C, profil Z, dan profil Omega. Masing - masing profil memiliki kegunaannya tersendiri. Profil $\mathrm{C}$ dan Profil Z biasa digunakan untuk struktur rangka utama kuda-kuda pada rangka atap. Untuk konstruksi pendukung seperti reng sebagai tempat kedudukan penutup atap/genteng digunakanlah profil Omega.

Dari penelitian-penelitian sebelumnya, didapat beberapa kelemahan baja ringan, diantaranya keruntuhan pada elemen strukturnya. Baja ringan memiliki beberapa fenomena keruntuhan, diantaranya adalah terjadi kerutan atau tekuk yang diamati pada batang tekan berlangsung secara tiba-tiba dan sangat berbahaya (Ugural, 1981), distorsi dari penampang yang ditandai oleh gerakan di garis lipatan (Davies dan Jiang, 1998), Tekuk lokal ditandai dengan panjang gelombang yang relatif pendek pada elemen pelat itu sendiri (Davies, 2000). Seraca umum disimpulkan bahwa baja ringan dapat digunakan sebagai elemen struktur tetapi cenderung ramping dan rentan terhadap kegagalan stabilitas termasuk: lentur keseluruhan kolom, torsi dan lentur-torsi pola tekuk, tekuk lokal, dan tekuk distotif (Young dan Jintang, 2002).

Dari segi perhitungan, perhitungan baja ringan sangat rumit dan memakan waktu, karena harus memperhitungkan luas efektif, beberapa hal seperti tekuk distorsi dan tekuk lokal juga harus dipertimbangkan. Perhitungan untuk tegangan saat kritis harus di trial and error sampai mendapat nilai tegangan yang benar-benar kritis. Untuk itu diperlukan metode lain yang dapat mempersingkat waktu untuk mendapatkan nilai kuat tekan dari baja ringan. Berdasarkan latar belakang diatas, maka penelitian ini dibuat. 


\section{Identifikasi Permasalahan}

Penelitian akan mencari tentang pengaruh panjang elemen terhadap kuat tekan (Pcr) dari baja ringan, pertama dihitung dengan menggunakan cara teoritis, kemudian dibandingkan hasilnya dengan cara metode elemen hingga.

\section{Batasan Masalah}

Agar penelitian ini terfokus pada 1 masalah yang spesifik, batasan-batasan masalahnya adalah :

1. Analisis numerik, FEM menggunakan program Abaqus dengan tipe elemen shell, homogen dan tidak memperhitungkan tegangan sisa.

2. Profil yang digunakan untuk penelitian adalah C-Chanel (75mm x $35 \mathrm{~mm} \times 5 \mathrm{~mm} \times 0,65 \mathrm{~mm})$.
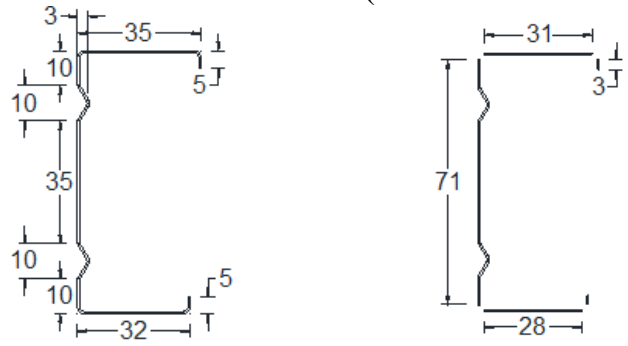

Gambar 1. Penampang C-Chanel (Sumber: SNI 7971:2013)

3. Perletakan yang digunakan adalah sendi-sendi.

4. Panjang benda uji adalah $0,5 \mathrm{~m} ; 1 \mathrm{~m} ; 1,5 \mathrm{~m} ; 2 \mathrm{~m} ; 2,5 \mathrm{~m}$.

\section{KAJIAN PUSTAKA}

\section{Luas Efektif Lip}

Langkah pertama dalam desain menggunakan metode Luas Efektif adalah mencari luas efektif dari masing-masing bagian penampang. Yang pertama dicari adalah Luas Efektif Lip dengan persamaan-persamaan berikut ini

$$
\begin{aligned}
& \Psi=\frac{\mathrm{f} 1}{\mathrm{f} 2} \\
& k=\frac{0.578}{\Psi+0.34} \\
& F_{c r}=\left\{\frac{k * \pi^{2} * E}{12\left(1-v^{2}\right)}\right\}\left(\frac{t}{b}\right)^{2} \\
& \lambda=\sqrt{\frac{f}{F_{c r}}} \\
& \rho=\frac{1-\frac{0.22}{\lambda}}{\lambda} \leq 1 \\
& \text { be }=\rho \times b
\end{aligned}
$$

Dengan $\mathrm{f} 1$ dan $\mathrm{f} 2$ adalah tegangan yang terjadi di lip, $\mathrm{k}=$ kekakuan, $\mathrm{Fcr}=$ tegangan kritis, $\mathrm{E}=$ modulus young, $\mathrm{v}=$ poisson's ratio, $t=$ tebal, $b=$ panjang lip, $f=$ tegangan yang terjadi di penampang, $\rho=$ faktor reduksi efektif.

\section{Luas Efektif Flens}

Untuk mencari luas efektif flens digunakan rumus-rumus dan tabel berikut ini

$$
S=1,28 \sqrt{\frac{E}{f}}
$$




$$
\begin{aligned}
& I a=399 t^{4}\left(\frac{w}{t S}-0,328\right)^{3} \leq t^{4}\left(115 \frac{w}{t S}+5\right) \\
& I s=\frac{d^{3} t \operatorname{Sin}^{2} \theta}{12} \\
& n=\left(0,582-\frac{w}{t S}\right) \geq \frac{1}{3}
\end{aligned}
$$

Tabel 1. Nilai koefisien tekuk pelat (Sumber: SNI 7971:2013)

$$
\begin{aligned}
& \begin{array}{|l|l|c|}
\hline \multicolumn{3}{|c|}{\text { Koefisien tekuk pelat }(k)} \\
\cline { 1 - 2 } \text { Pengaku tepi lip sederhana }\left(140^{\circ} \geq \theta \geq 40^{\circ}\right) & \multirow{2}{*}{\text { Pengaku tepi yang lain }} \\
\hline d_{1} / b \leq 0,25 & 0,25 \leq d_{1} / b \leq 0,8 & 3,57\left(\frac{I_{s}}{I_{\mathrm{a}}}\right)^{n}+0,43 \leq 4 \\
3,57\left(\frac{I_{\mathrm{a}}}{I_{\mathrm{s}}}\right)^{n}+0,43 \leq 4 & \left(4,82-\frac{5 d_{l}}{b}\right)\left(\frac{I_{\mathrm{s}}}{I_{\mathrm{a}}}\right)^{n}+0,43 \leq 4 &
\end{array} \\
& F_{c r}=\left\{\frac{k \cdot \pi^{2} * E}{12\left(1-v^{2}\right)}\right\}\left(\frac{t}{b}\right)^{2} \\
& \lambda=\sqrt{\frac{f}{F_{c r}}} \\
& \text { be }=\rho \times b, j i k a \lambda>0,673 \\
& \text { be }=b, j i k a \lambda<0,673
\end{aligned}
$$

Dengan $\mathrm{S}=$ variabel untuk mencari Ia,Is, dan $\mathrm{k}, \mathrm{Ia}=$ Inersia yang memadai, Is= inersia pengaku, $\mathrm{n}=\mathrm{koefisien}$ untuk mencari kekakuan, k= kekakuan, be= lebar efektif flens.
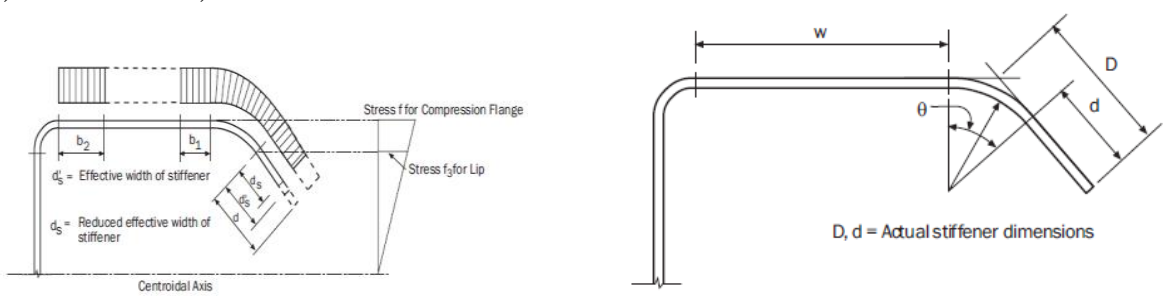

Gambar 2. Letak-letak bagian flens (Sumber: SNI 7971:2013)

\section{Luas Efektif Web}

Untuk mencari luas efektif web digunakan rumus-rumus dan tabel berikut ini

$$
\begin{aligned}
& R=\frac{11-\frac{b_{0}}{h}}{5} \geq \frac{1}{2}, j i k a \frac{b_{0}}{h}>1 \\
& R=2, j i k a \frac{b_{0}}{h}<1 \\
& \beta=(1+\gamma(n+1))^{\frac{1}{4}} \\
& \gamma=\frac{10,92 I_{s p}}{b_{0} t^{3}} \\
& \delta=\frac{A_{s}}{b_{0} t} \\
& k_{d}=\frac{\left(1+\beta^{2}\right)^{2}+\gamma(1+n)}{\beta^{2}(1+\delta(n+1))} \\
& k_{l o c}=4(n+1)^{2}
\end{aligned}
$$




$$
\begin{aligned}
& \lambda=\frac{1.052}{\sqrt{k}}\left(\frac{b_{o}}{t}\right) \sqrt{\frac{f}{E}} \\
& \rho=1, j i k a \lambda<0,673 \\
& \rho=\frac{\left(1-\frac{0.22}{\lambda}\right)}{\lambda}, j i k a \lambda>0,673 \\
& b_{e}=\rho\left(\frac{A_{g}}{t}\right)
\end{aligned}
$$

Dengan $\mathrm{R}=$ faktor modifikasi untuk koefisien tekuk distorsi pelat, $\beta, \gamma, \delta=$ koefisien yang digunakan untuk menhitung $\mathrm{kd}, \mathrm{kd}=$ koefisien tekuk torsi pelat untuk tekuk distorsi, kloc= koefisien tekuk lokal elemen pelat untuk tekuk subelemen lokal, be= panjang efektif web.

\section{Luas Efektif}

Untuk mendapatkan luas efektif total, perhitungannya adalah Luas total $-\Sigma(\mathrm{b}-\mathrm{be}) \mathrm{xt}$

\section{Kuat Tekan}

Setelah mendapat Luas Efektif dari penampang, dicari nilai Fn untuk menghitung Nc, namun untuk baja G550 dengan ketebalan di bawah $0,9 \mathrm{~mm}$ perlu dilakukan pengecekan dulu terhadap radius girasinya dengan cara jika Le $<1,1$ Lo maka r perlu dikalikan dengan faktor reduksi $\gamma$.

$$
\begin{aligned}
& F_{c r}=\left\{\frac{k \times \pi^{2} \times E}{12\left(1-v^{2}\right)}\right\}\left(\frac{t}{b w 2}\right)^{2} \\
& L o=\pi \times r \times \sqrt{\frac{E}{f_{c r}}} \\
& \gamma=0.65+\left(\frac{0.35 l_{e}}{1.1 l_{o}}\right) \\
& r=\sqrt{\frac{I}{A}} \\
& F_{o c}=\frac{\pi^{2} E}{(K L / r)^{2}} \\
& \lambda_{c}=\sqrt{\frac{F_{y}}{F_{o c}}} \\
& F_{n}=\left(0,658^{\lambda_{e}^{2}}\right) \times F_{y}, j i k a \lambda c<1,5 \\
& F n=\left(\frac{0,877}{\lambda_{c}^{2}}\right) F_{y}, \text { jika } \lambda c>1,5 \\
& N=A e \times F n
\end{aligned}
$$

\section{METODE ELEMEN HINGGA}

Metode Elemen Hingga (MEH) adalah metode numeris untuk penyelesaian masalah teknik dan fisika matematis. Masalah yang dapat diselesaikan bermacam-macam, seperti analisa struktur, heat transfer, aliran fluida, perpindahan massa, elektromagnetik, dsb. Dalam perhitungan tegangan dan regangan, untuk mendapat perhitungan yang lebih akurat, perlu diperhatikan faktor-faktor lain yang berpengaruh dalam perhitungan, seperti geometri pembebanan, dan sifat material. Namun dengan dimasukannya faktor-faktor tersebut akan sangat sulit dan lama untuk menyelesaikan perhitungan secara matematis. Cara kerja Metode Elemen Hingga adalah dengan memecah (mendiskritisasi) model dari objek dengan membagi objek kedalam elemen-elemen yang lebih kecil (finite element atau elemen hingga) yang terhubung oleh titik-titik (nodes) yang digunakan oleh elemen-elemen tersebut dan sebagai batas dari elemen hingga. Karena terjadi diskritisasi maka perhitungan metode elemen hingga menjadi sangat banyak jika dikerjakan secara manual, maka diperlukan bantuan program untuk pengerjaannya. Beberapa 
program untuk pengerjaan metode elemen hingga adalah GT STRUDL, CATIA, StruCAD, SAP2000, ABAQUS, FLUENT, ALGOR, IDEAS, CFX, ANSYS, ADINA, FEMAP, MSC NASTRAN, MSC PATRAN, ROBOT (AUTODESK), MSC DYTRAN, MSC MARC, SACS, MICRO SAS. Berikut adalah cara pengerjaan pemodelan Abaqus.

Pertama dimasukan model penampang dan jenis elemen shell serta panjang dari penampang.

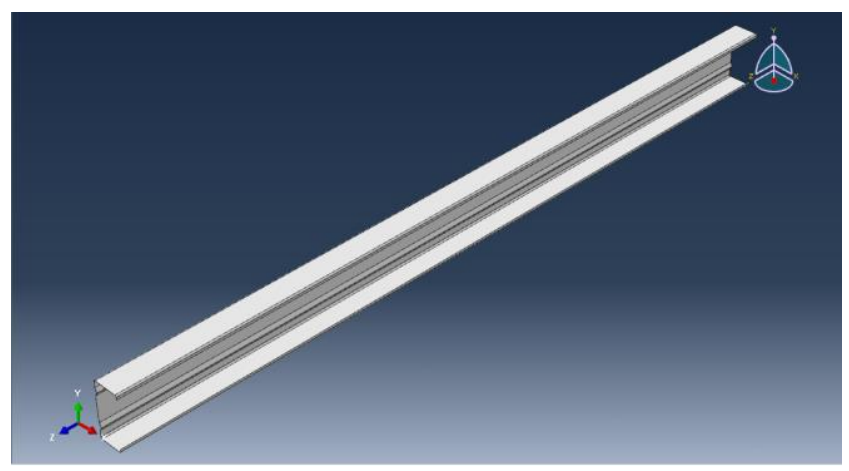

Gambar 3. Model penampang.

Kemudian masukan data properti penampang
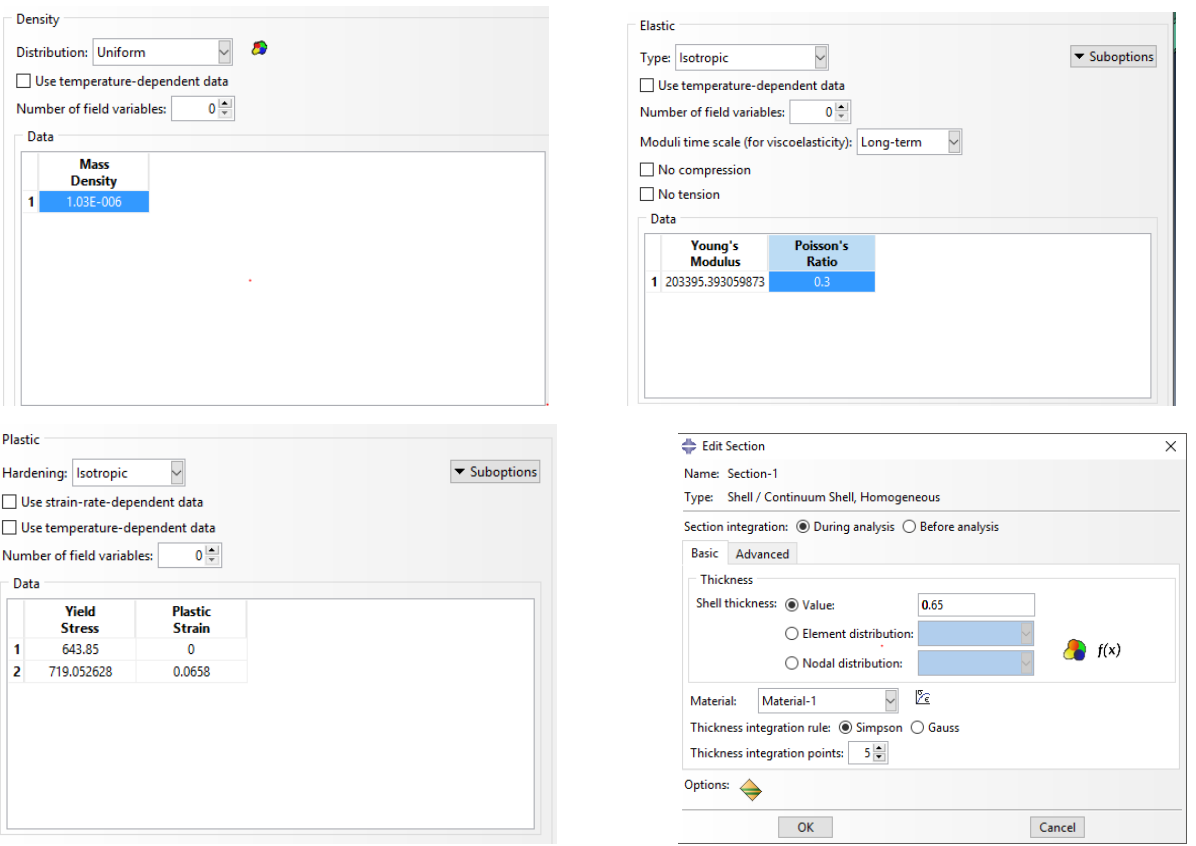

Gambar 4. Properti penampang.

Step yang digunakan adalah Static Riks

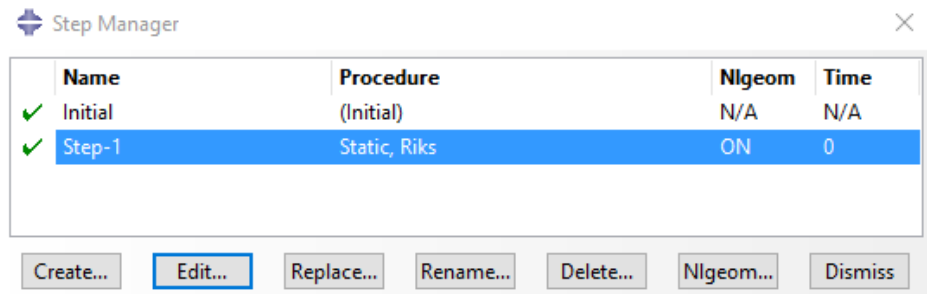

Gambar 5. Step 
Interaction diisi dengan Refrence Point dan MPC tipe ties

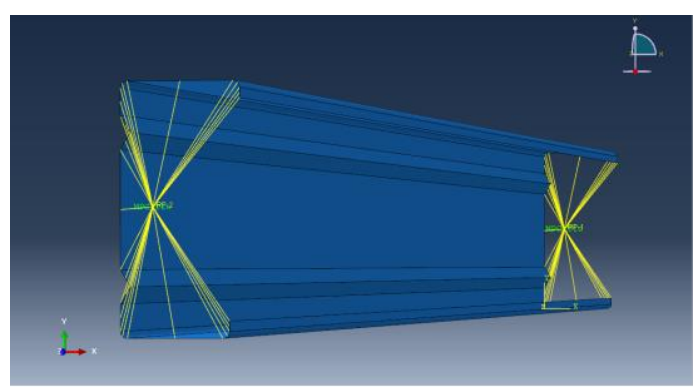

Gambar 6. Refrence Point dan MPC

Setelah itu dimasukan beban dan perletakan.

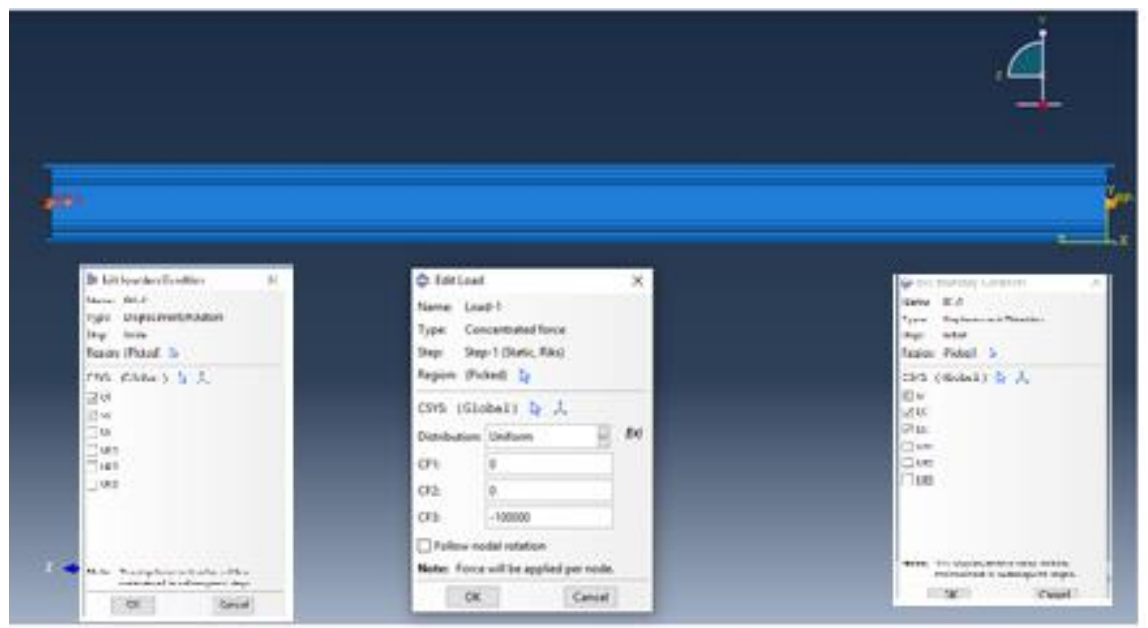

Gambar 7. Beban dan perletakan

Langkah terkahir adalah diskritisasi dari penampang

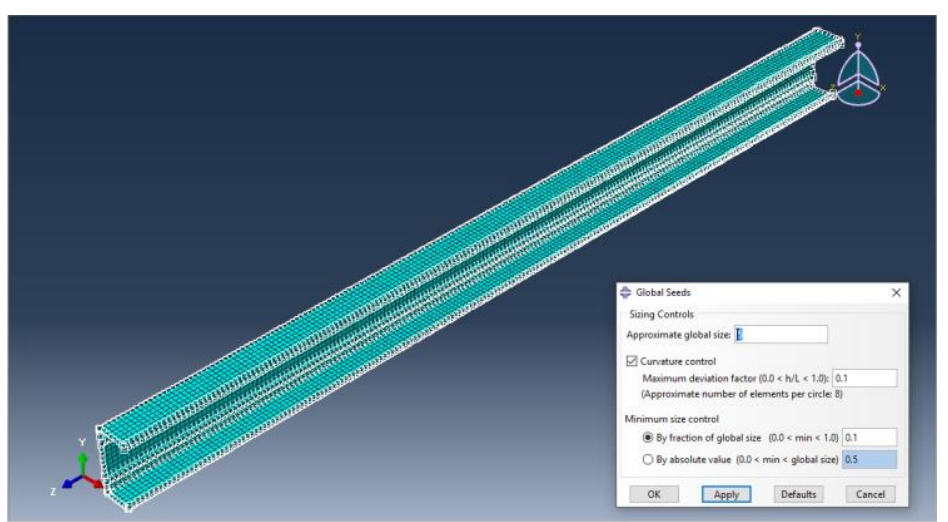

Gambar 8. Diskritisasi

\section{ANALISIS DAN PEMBAHASAN}

\section{Hasil analisis Abaqus}

Berikut adalah tegangan dan defleksi dari setiap panjang elemen berurutan dari 0,5m sampai 2,5m: 
Jurnal Mitra Teknik Sipil

Vol. 1, No. 1, Agustus 2018: hlm 159-167
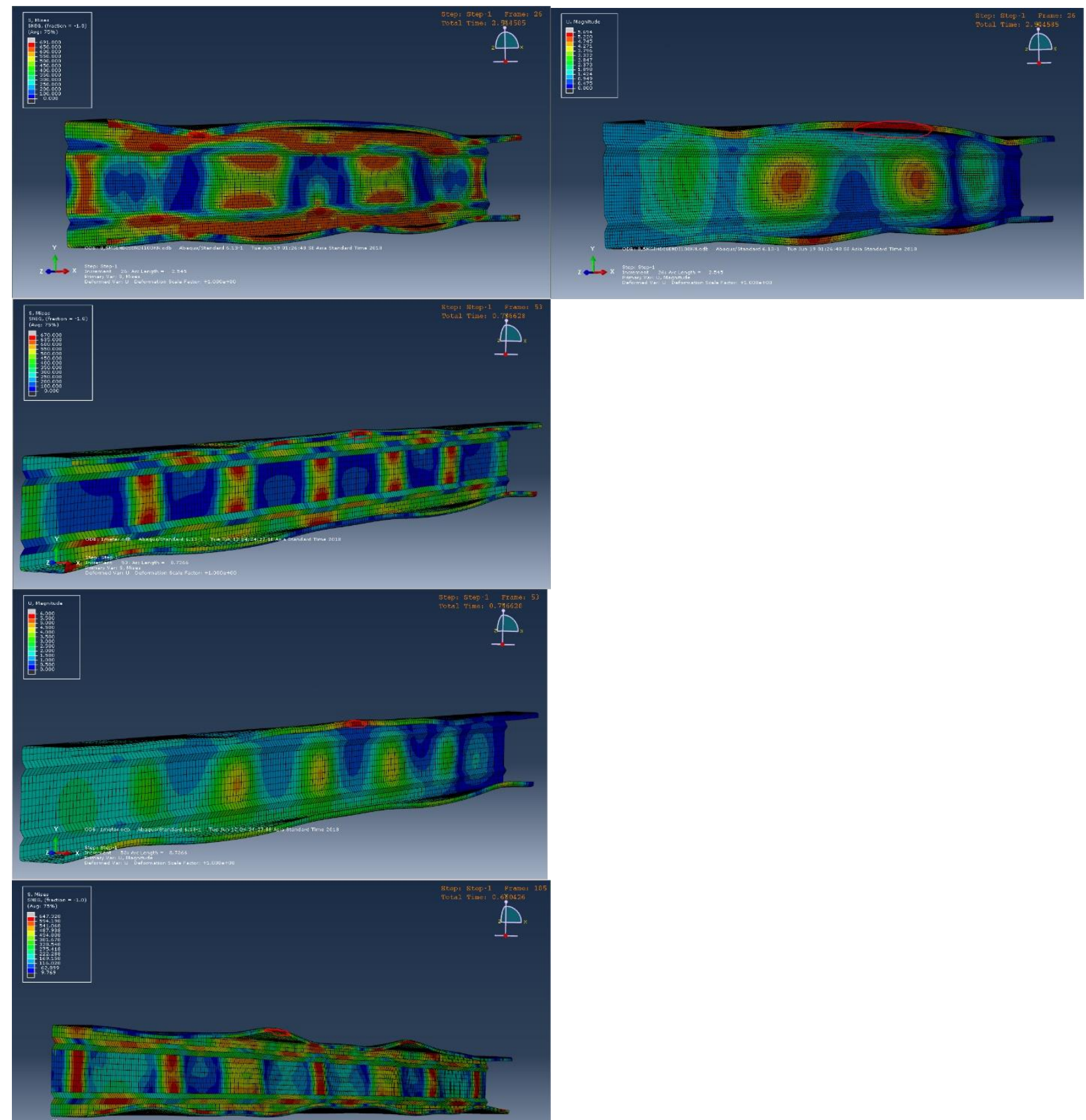

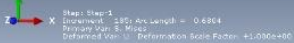

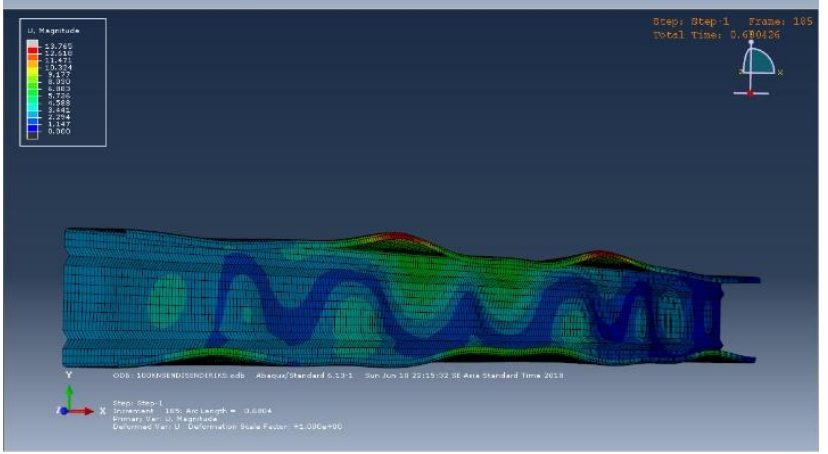




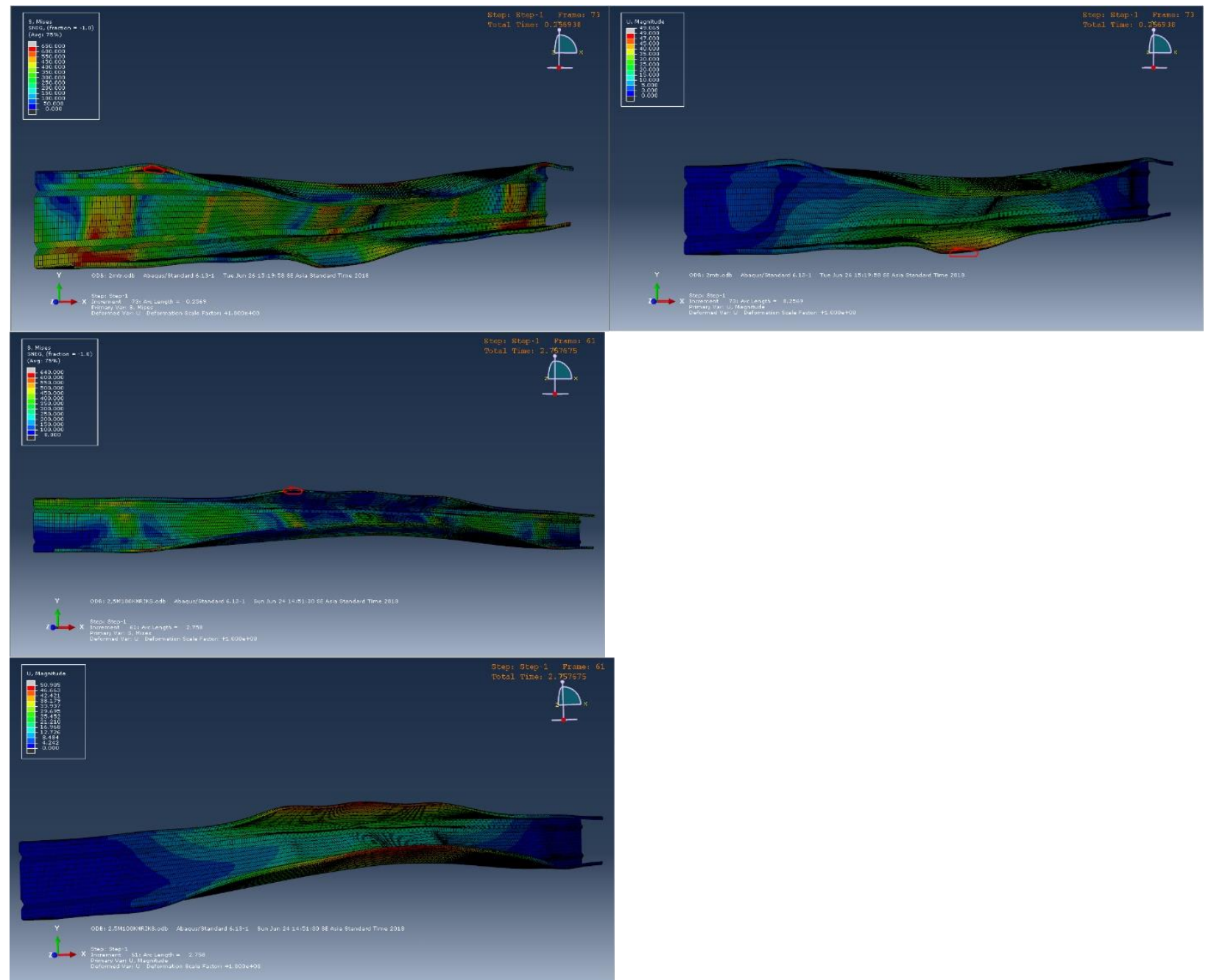

Gambar 3. Tegangan, deformasi, mode tekuk model pertama sampai ke lima. 
Tabel 2. Perbandingan hasil hitungan teoritis dan Metode Elemen Hingga

\begin{tabular}{|c|c|c|c|}
\hline Panjang $(\mathrm{mm})$ & Teoritis $(\mathrm{KN})$ & MEH $(\mathrm{KN})$ & Perbedaan $(\%)$ \\
\hline 500 & 42.162 & 27.53 & 34.704 \\
\hline 1000 & 36.512 & 25.3584 & 30.548 \\
\hline 1500 & 30.348 & 22.3 & 26.519 \\
\hline 2000 & 22.893 & 15.25 & 27.009 \\
\hline 2500 & 16.685 & 11.5 & 31.076 \\
\hline
\end{tabular}

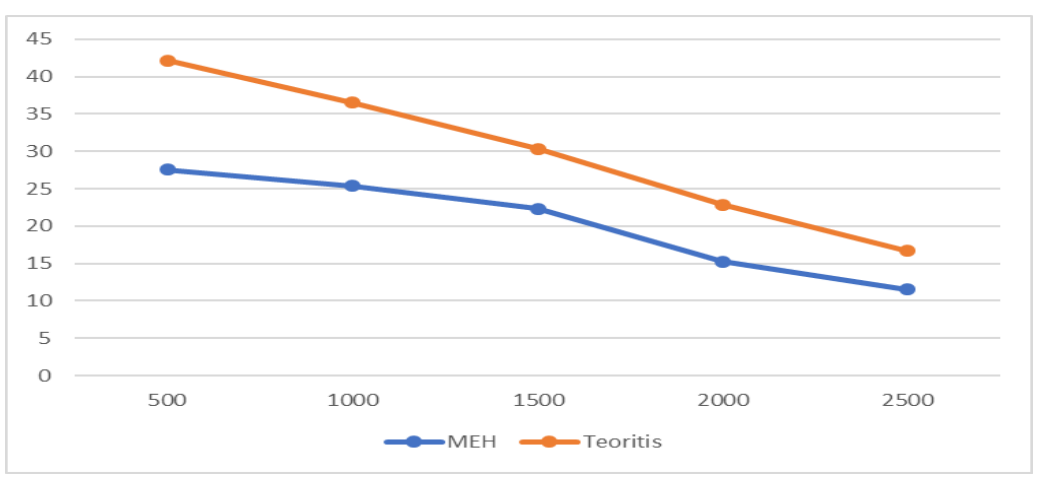

Gambar 4. Grafik perbedaan hasil teoritis dan Metode Elemen Hingga.

\section{KESIMPULAN DAN SARAN}

\section{Kesimpulan}

Dari hasil analisis Metode Elemen Hingga dan teoritis maka dapat diambil beberapa kesimpulan sebagai berikut :

1. Beban tekan kritis (Pcr) yang dihasilkan antara model pertama $(0,5 \mathrm{~m})$, model kedua (1m), model ketiga $(1,5 \mathrm{~m})$, model keempat $(2 \mathrm{~m})$, dan model kelima (2,5m) secara berurutan adalah 42,162 KN; $36,512 \mathrm{KN}$; $30,348 \mathrm{KN} ; 22,893 \mathrm{KN} ; 16,685 \mathrm{KN}$ menunjukan bertambahnya panjang elemen akan menurunkan kuat tekan penampang tersebut. Hal ini juga didukung dari hasil analisis Metode Elemen Hingga secara berurutan yaitu $27,52 \mathrm{KN} ; 25,36 \mathrm{KN} ; 22,3 \mathrm{KN} ; 15,25 \mathrm{KN} ; 11,5 \mathrm{KN}$.

2. Deformasi maximum yang dihasilkan antara model pertama hingga kelima secara berurutan adalah 5,7mm; 5,9 $\mathrm{mm} ; 12,32 \mathrm{~mm} ; 49 \mathrm{~mm}$; 50mm menunjukan semakin panjang elemen, deformasi yang dihasilkan juga semakin besar.

3. Berdasarkan kegagalan pada model pertama hingga keempat, tekuk yang terjadi pada semua model adalah tekuk lokal (bagian flens) menunjukan kalau profil ini memerlukan pengaku yang lebih kuat pada bagian flens.

4. Perbedaan nilai Pcr yang cukup jauh terjadi pada model pertama yaitu sebesar $35 \%$ menunjukan model Abaqus kurang cocok digunakan untuk perhitungan kolom pendek.

\section{DAFTAR PUSTAKA}

Dewobroto, W. (2015). Struktur Baja "Perilaku, Analisis, dan Desain - AISC 2010." Tangerang, Banten: Jurusan Teknik Sipil Universitas Pelita Harapan, LUMINA Press.ATC-40. (1996).

Getting Started With Abaqus. Tersedia di www.engineering.ucsb.edu/ tshugar/GET_STARTED.pdf (13 Juni 2018).

Latumeten, Regyna A.D. Perencanaan Struktur Rangka Atap Baja Canai Dingin. Tersedia di www.media.neliti.com/ media/publications/79127-ID-perencana an-struktur-rangka-atap-baja-ca.pdf (4 Maret 2018).

Metode Elemen Hingga. Tersedia di www.personal.its.ac.id/files/material/2983-handayanu-oe01.METODE\%20ELEM EN \%20HINGGA\%20pengantar1. pdf (17 May 2018).Badan Standarisasi Nasional. (2013).

Setiyawan, Unggul. Struktur Tekan. Tersedia di www.academia.edu/7942885/4-STRUKTUR TEKAN (20 Juni 2018).

Studi Baja Ringan dan Baja Konvensional. Tersedia di www.elib.unikom.ac.id/ files/disk1/654/jbptunikompp-gdlmadeenager-32656-11-unikom_m-i.pdf (5 Maret 2018).

Standar Nasional Indonesia 7971 (2013). “Struktur Baja Canai Dingin.” Jakarta: Badan Standardisasi Nasional. 
Sucipta, Andry. Analisa Pola Keruntuhan Konstruksi Rangka Atap Dengan Menggunakan Profil Baja ringan. Tersedia di www.download.portalgaruda .org/artile.php?article= 147096\&val=5847 (5 Maret 2018).

Sulistyorini, Dwi Kusuma. Baja ringan sebagai alternatif bahan bangunan. Tersedia di www.dwikusumadpu. wordpress.com/2013/04/20/baja-ringan-sebagai-alternatif-bahan-bangunan/ (5 Maret 2018).

www.abaqus.software.polimi.it/v6.14/books/usb/default.htm?startat=pt06ch29s06ael17.html (27 Mei 2018).

Yu, W. (2000). "Cold-Formed Steel Design.” Edisi 3, Canada. 